\title{
QUALITATIVE AND BIOASSAY ASSESSMENT OF GLYPHOSATE HERBICIDE USING CERTAIN GROUND SPRAYERS AND DIFFERENT APPLICATION RATES IN MANGO ORCHARDS
}

\author{
AMMAR, A. E. \\ Spray technology dep., plant protection Res. Institute. ARC, Giza , Egypt
}

(Manuscript received 15 January 2012)

\begin{abstract}
Two field experiments were undertaken in El - Ismaillia regions, Egypt to evaluate the performance of different spraying volumes and rate of glyphosate herbicide on annual and perennial weeds control in mango fields 7 years old orchard during 2009 and 2010 summer seasons .

Spraying equipment tested were Cp-3 sprayer fitted with TK1 125 L./Fed. or flat fan 02- F110 nozzles 60 L./Fed., Micron Ulva sprayer $19 \mathrm{~L}$./Fed. and Besho sprayer fitted with fan style spray head $70 \mathrm{~L}$./Fed. with the use of rates doses of glyphosate (Herbazid $48 \%$ wsc) i.e. 4.0, 2.5 and 1.25 L./Fed. with TK1 nozzle, 2.5 and 1.25 L./Fed. with both flat fan 02- F110 nozzle, Ulva sprayer and Besho sprayer as compared with hand hoeing and unweeded check. Each experiment was included eleven treatments in a complete randomized block design with four replicates.

Data indicated that the using of flat fan 02- F110 nozzel and Micron Ulva sprayer (Herbi) can reduced glyphosate rate dose to 2.5 L./Fed. compared with TK1 nozzle at rate dose 4 L./Fed. without effect on weed control efficacy. The same sprayers were reduced the contamination of applicator to $6.44,10 \%$ in the first season and $9.1,10.1 \%$ in the second season respectively, at the same rate dose of $2.5 \mathrm{~L}$./Fed. the percentage control which obtained by these spraying volumes were $91.3 \%$ and $85.8 \%$ in the first season and $94 \%$ and $86.9 \%$ in the second season respectivily, as compared with TK1 125 L./Fed. spraying volume which gave $94.1 \%$ and $96.7 \%$ for the first and second seasons respectively at rate dose of 4 L./Fed. of glyphosate. In case of Besho sprayer 70 L./Fed. spraying volume gave satisfactory coverage on weed leaves and excellent control of weeds. The low rate of glyphosate at rate dose $1.25 \mathrm{~L}$./Fed. gave good efficacy in controlling annual weeds which reached $82.3 \%$ control for existed weeds and exceeded hand hoeing.

Thus it could be concluded that, low volume spraying could reduced glyphosate rate dose without any significant reduction in control efficacy of total weeds and decreasing the amount of contamination of applicator and reduced lost spray on land and other possible risks on the environment.
\end{abstract}

\section{INTRODUCTION}

The pesticide action is affected by several interfering factors, e.g. the pesticide type and its characters and spray quality. Herbicides are usually applied in aqueous solution or suspension as could of droplets directed toward the target which 
play a great role in determining the biological efficacy of the treatment. Within certain limits, smallest droplet the better is the actual efficacy. Accordingly, the application methods of a pesticide has decisive influence on the pesticidal action against the target pest. Moreover, measures aiming to minimizing drift or dropping the sprayed droplets during application are highly required economically and environmentally.

Glyphosate is non-selective, translocated herbicide, environmentally friendly for weed control in horticulture plantation, but potential of spray drift in these crops should be present in concern.

Spray spectrum can play a good role in managing this problem as mentioned by many researchers Barzee and Stroube (1972) found that liquid formulations of herbicides could be applied at low carrier volumes with weed control similar to that obtained with conventional application. Feng. et. al. (1998) reported that, large droplet size of relatively concentrated herbicide induce epidermal disruption and localized cell necrosis. Fietsam et. al. (2004) indicated that spray coverage of the weed canopy was reduced with use of the low drift nozzle where extended range flat fan $(X R)>$ pre-orfice flate fan $(D G)>$ turbo flat fan $(T T)>$ venture flat fan $(P A)$, spray droplet density was also generally reduced with the use of low drift nozzle.

The present investigation aimed to spot light on the relation between different spraying volumes and rates doses of glyphosate to control weed. Also, the herbicidal activity of this herbicide when sprayed by Cp-3 sprayer with TK1 or flat fan 02- F110 nozzle, Micron Ulva sprayer (Herbi) and Besho sprayer with fan style spray head in Mango orchards fields.

\section{MATERIALS AND METHODS}

Two field experiments were carried out in El- Ismailia governorate during 2009 and 2010 summer seasons naturally heavily infested with annual and perennial weeds to evaluate the performance of three different sprayers and glyphosate rate doses on droplet number, droplet size and weed control in citrus orchard (Mango 7 years old).

\section{1- Equipments used}

\section{1-1- Micron Ulva sprayer (Herbi)}

The equipment consists of two mean parts: a micropek, which is a $10 \mathrm{~L}$. tank for spray mix carried like a knapsack by the applicator and Micron Ulva sprayer. In Egypt, these sprayers are used to apply the normal emulsifiable concentrate products mixed with water at spray volume 4 L./Fed.. Four big sizes dry batteries are fitted in the 
handle to provide power to supply spinning cup with rotation. As the liquid from the spray falls onto the spinning cup, it is broken into very fine droplets. (Table, 1 ).

\section{1-2- Cooper Pegler sprayer (Cp-3)}

This sprayer was classified as a lever- operated sprayer with diaphragm pump and connected with the pump handle by a crankshaft mechanism. The $\mathrm{Cp}_{\mathbf{3}}$ sprayer was fitted with two types of nozzles: (Tk1, and 02-F110 nozzles). (Table, 1)

Table 1. Technical data of the spraying techniques.

\begin{tabular}{|c|c|c|c|c|c|}
\hline \multirow[t]{2}{*}{ Item } & \multirow{2}{*}{$\begin{array}{c}\text { Micron Ulva } \\
\text { sprayer } \\
\text { (Herbi) }\end{array}$} & \multicolumn{2}{|c|}{$\begin{array}{l}\text { C-P-3 sprayer } \\
\text { fitted with }\end{array}$} & \multirow[t]{2}{*}{ Besho Sprayer } & \multirow[t]{2}{*}{ Conditions } \\
\hline & & $02-\mathrm{F} 110$ & TK1 & & \\
\hline Nozzle type & Spinning disc & Flat- fan & Deflector & Fan style spray head & Hydrolic nozzles \\
\hline Spraying volume (L./Fed.) & 19 & 60 & 125 & 70 & - \\
\hline Swath width (m.) & 1 & 0.75 & 1.5 & 0.75 & Effective \\
\hline Flow rate (L./Min) & 0.180 & 0.428 & 1.79 & 0.500 & - \\
\hline Mean working speed $(\mathrm{km} / \mathrm{h})$ & \multicolumn{3}{|c|}{ In all treatment } & - & Mean $\pm 5 \%$ \\
\hline Type of the spray used. & \multicolumn{3}{|c|}{ In all treatment } & - & - \\
\hline Mean spray height, $(\mathrm{m})$ & \multicolumn{3}{|c|}{ In all treatment } & - & - \\
\hline
\end{tabular}

\section{1-3- Knapsack style manual sprayer (Besho)}

The machine is composed of container of liquid (20 litter), pump and air chamber, spraying system (including rubber hose and components, switch, sprayer spindle and head), operation arm and components and backpack belt system. Shawn (Table, 1).

\section{Sampling line}

A complete randomized block design was used. The plot area was $59 \times 9 \mathrm{~m}$. Herbicide treatments were carried out at August 10 and 15 for the first and second seasons, respectively. The sampling line was consisted of 6 wire holder fixed in diagonal line inside each treatment to collect droplet sprayed Sex sensitive cards were distributed on weeds at distance of one meter and 5 cards distributed on applicator (one card on head, two cards on thorax/abdomen and two cards on legs). The herbicid used was glyphosate $\mathrm{N}$-(phosphonmethyl) glycine isopropyl ammonium salt. It is non selective, broad spectrum, post emergence, located herbicide for annual and perennial weed control. The trade name is Herbazed $48 \%$ WSC .

Each experimental included eleven treatments as follows:

1- Herbazed at rate dose 4.0 L./Fed. with TK1 nozzle at $125 \mathrm{~L}$. water/Fed.

2- Herbazed at rate dose $2.5 \mathrm{~L}$./Fed. with TK1 nozzle at $125 \mathrm{~L}$. water/Fed.

3- Herbazed at rate dose $1.25 \mathrm{~L} . /$ Fed. with TK1 nozzle at $125 \mathrm{~L}$. water/Fed.

4- Herbazed at rate dose 2.5 L./Fed. with 02-F110 nozzle at $60 \mathrm{~L}$. water/Fed. 
5- Herbazed at rate dose 1.25 L./Fed. 02-F110 nozzle at $60 \mathrm{~L}$. water/Fed.

6- Herbazed at rate dose $2.5 \mathrm{~L}$./Fed. with Ulva sprayer (Herbi) at $19 \mathrm{~L}$. water/Fed.

7- Herbazed at rate dose 1.25 L./Fed. with Ulva sprayer (Herbi) at $19 \mathrm{~L}$. water/Fed.

8- Herbazed at rate dose $2.5 \mathrm{~L}$./Fed. with Besho sprayer at $70 \mathrm{~L}$. water/Fed.

9- Herbazed at rate dose 1.25 L./Fed. with Besho sprayer at $70 \mathrm{~L}$. water/Fed.

10- Hand hoeing

11- Unwedded check.

Spray droplets were received on sensitive cards which were obtained from (Novartis) Company which distributed randomly on weeds. The program of calibration was done according to Gabir et. al. (1982). Data of weed densities were subjected to analysis according to Sendcor and Cochran (1980). The least significant difference (LSD) at $5 \%$ level of significance was calculated. The measured spots were translated to spherical droplets by means of the spread factor.

\section{Data recorded}

All sensitive cards were collected carefully for measuring and calculating by special scaled monocular lens of $\left(\right.$ struben $\left.^{\circledR}\right)$ with magnification of $15 x$. Droplet were recorded as follows:

- Droplet size $(\mu \mathrm{m})$ on weeds lost spray on land and cards on applicator.

- Number of droplets/ $\mathrm{cm}^{2}$ on weeds, land and applicator.

Weeds were surveyed and classified according to Tackholm (1974) and the following data were recorded:

- Fresh weight of annual broadleaf, grassy and total weeds/ gm.

Controlling percentage $=$

$100 \mathrm{x}$ fresh weight in unweeded check- fresh weight in herbicide treatment fresh weight in unweeded check.

\section{RESULTS AND DISCUSSION}

\section{1- Effect of different spraying volumes and rates doses of glyphosate application on spray spectrum}

The efficiency of the tested techniques ware evaluated qualitatively based on the characteristics of deposited spectrum of droplet on annual and perennial weeds in Mango orchards. The Cp-3 sprayer with two different nozzles (TK1 nozzle, flat fan 02F110 nozzle), spinning disc sprayer (Herbi) and Besho sprayer fitted with fan style spray head were used to spray herbicide solution at two spraying volumes (125 and 60 L./Fed.) and three rates doses of glyphosate (4, 2.5 and 1.25 L./Fed.) and (70 
L./Fed. spraying volume and two rates of glyphosate, i.e. 2.5 and 1.25 L./Fed.) for the Besho sprayer fitted with fan style spray head as shown in table (2).

Data are in agreement with Swarbrick and Mercado (1987), they reported that spray volumes used for applying herbicides were varied between 5 and 2000 L/ha. The volume used for spraying a herbicide depends on :

- The amount and density of the foliage to be sprayed.

- The amount of fresh water available.

- The type of equipment used and nozzle or atomizer's size fitted on it .

- The type of herbicide used.

- The environmental conditions at the time of spraying.

The dominant annual broad leaf weeds in the experimental area during the two seasons were: Euphorbia geniculate Orlega, Solanum nigrun La, Chonopodium album L., Xanthium spinosum L. and Amaranthus hybridus L. the dominant annual grass weeds were Bromus sp, Setaria viridian L., Echimochloa colonum L. and Eleusine indica L. the perennial weed were Cyperus rotudus $\mathrm{L}$. and Cynodon dactylon L.

\subsection{Spray deposit on weed surface}

Data in table (2) presents the spray deposits on weeds as produced by the tested sprayer, by three rates doses of glyphosate (Herbazed $48 \%$ ) WSC. for the two successive seasons 2009 and 2010. The following indicators could be concluded from the obtained results:

In general, all the tested spraying techniques gave satisfactory coverage on weed i.e. more than 25 droplets $/ \mathrm{cm}^{2}$ of $287-425 \mu \mathrm{m}$. However, Micron Ulva sprayer (Herbi) at 19 L./Fed. gave the best coverage i.e. 60 droplets of $289 \mu \mathrm{m}$. The values of this treatment was found to be less than the optimum size recommended by Ciba Geigy, 1990 for herbicide sprays. The optimum spectrum of droplet suitable for controlling weeds of field crop should be sized between $200-400 \mu \mathrm{m}$ (VMD) with number not less than 20 droplet $/ \mathrm{cm}^{2}$ distributed homogeneously on the treated target. 
Table 2. Effect of different spraying volumes and rates doses of glyphosate herbicide on spray deposits on weeds, lost spray on land and applicators in Mango orchards at 2009-2010 seasons .

\begin{tabular}{|c|c|c|c|c|c|c|c|c|c|c|c|c|c|c|c|}
\hline \multirow{4}{*}{$\begin{array}{c}\text { Rate doses of } \\
\text { Glyphosate } \\
\text { L./fed. }\end{array}$} & \multirow{4}{*}{\multicolumn{2}{|c|}{ Equipment }} & \multirow{5}{*}{$\begin{array}{c}\text { Spray } \\
\text { volume } \\
\text { L./fed } \\
125\end{array}$} & \multicolumn{12}{|c|}{ Spray deposits (Number of droplets $/ \mathrm{cm}^{2}$ and droplets size $\mu \mathrm{m}^{* * *}$ ) } \\
\hline & & & & \multicolumn{6}{|c|}{2009 season } & \multicolumn{6}{|c|}{2010 season } \\
\hline & & & & \multicolumn{2}{|c|}{ On weeds } & \multicolumn{2}{|c|}{ On land } & \multicolumn{2}{|c|}{ On applicator } & \multicolumn{2}{|c|}{ On weed } & \multicolumn{2}{|c|}{ On land } & \multicolumn{2}{|c|}{ On applicator } \\
\hline & & & & $\mathrm{N} / \mathrm{cm}^{2 *}$ & $\begin{array}{c}\mathrm{VMD}^{* *} \\
\mu \mathrm{m}\end{array}$ & $\mathrm{N} / \mathrm{cm}^{2}$ & $\begin{array}{l}\text { VMD } \\
\mu \mathrm{m}\end{array}$ & $\mathrm{N} / \mathrm{cm}^{2}$ & $\begin{array}{l}\text { VMD } \\
\mu \mathrm{m}\end{array}$ & $\mathrm{N} / \mathrm{cm}^{2}$ & $\begin{array}{l}\text { VMD } \\
\mu \mathrm{m}\end{array}$ & $\mathrm{N} / \mathrm{cm}^{2}$ & $\begin{array}{l}\text { VMD } \\
\mu \mathrm{m}\end{array}$ & $\mathrm{N} / \mathrm{cm}^{2}$ & $\begin{array}{l}\text { VMD } \\
\mu \mathrm{m}\end{array}$ \\
\hline 4 & \multirow{5}{*}{ 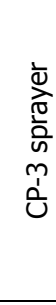 } & Tk1 & & 38 & 370 & 17 & 368 & 9 & 369 & 40 & 373 & 17 & 377 & 10 & 375 \\
\hline 2.5 & & Tk1 & 125 & 40 & 365 & 15 & 363 & 7 & 367 & 43 & 370 & 16 & 375 & 9 & 373 \\
\hline 1.25 & & Tk1 & 125 & 45 & 360 & 16 & 357 & 8 & 362 & 48 & 368 & 17 & 370 & 9 & 365 \\
\hline 2.5 & & 02-f110 & 60 & 87 & 320 & 20 & 330 & 7 & 325 & 89 & 300 & 18 & 305 & 10 & 307 \\
\hline 1.25 & & 02-f110 & 60 & 90 & 315 & 22 & 320 & 8 & 320 & 94 & 295 & 19 & 300 & 12 & 300 \\
\hline 2.5 & \multirow{2}{*}{\multicolumn{2}{|c|}{$\begin{array}{c}\text { Micron Ulva } \\
\text { sprayer (Herbi) }\end{array}$}} & 19.0 & 60 & 289 & 18 & 299 & 8 & 287 & 68 & 293 & 20 & 299 & 9 & 297 \\
\hline 1.25 & & & 19.0 & 72 & 287 & 20 & 297 & 11 & 286 & 76 & 292 & 22 & 297 & 12 & 295 \\
\hline 2.5 & \multirow{2}{*}{\multicolumn{2}{|c|}{$\begin{array}{c}\text { Besho+ fan style } \\
\text { spray head }\end{array}$}} & 70 & 25 & 397 & 8 & 400 & 6 & 405 & 30 & 415 & 12 & 420 & 7 & 420 \\
\hline 1.25 & & & 70 & 27 & 410 & 8 & 410 & 7 & 409 & 28 & 425 & 11 & 435 & 7 & 430 \\
\hline
\end{tabular}

$* \mathrm{~N} / \mathrm{cm}^{2}=$ Number of droplets $/ \mathrm{cm}^{2}$

$* * \mathrm{VMD}=$ Volume mean diameter

***

$\mu \mathrm{m}$

micron 
Results showed that the number of droplets $/ \mathrm{cm}^{2}$ was drastically affected by nozzle type and spray volume. It was increased with decreasing spray volumes that gave average $66,41,88.5$ and 26 droplet $/ \mathrm{cm}^{2}$ with spinning disc, TK1, flat fan 02F110 and fan style spray heads respectively during 2009. The corresponding values at the season 2010 were $72,43.7,91.5$ and 29 droplets $/ \mathrm{cm}^{2}$ with the same nozzles. On the other hand, droplet size tended to decrease with decreasing spray volume with various nozzles, where the average of droplet sizes were 288, 365, 317.5 and 403.5 $\mu \mathrm{m}$ with spinning disc, Tk1, flat fan 02-fl10 and fan style spray head, respectively at 2009 and 292.5, 370.3, 297.5 and $420 \mu \mathrm{m}$ for respective nozzles during 2010. Swarbrick and Mercado (1987) reported that droplets of 250-400 miron diameter are more convenient for spraying soil herbicides, they deposited quickly and evenly to the soil without drift. Flat fan 02-F110 nozzles increased number of droplets $/ \mathrm{cm}^{2}$ to 90 and decreased droplet size to $315 \mu \mathrm{m}$ compared with fan style spray head 27 droplets $/ \mathrm{cm}^{2}$ and $410 \mu \mathrm{m}$. Micron Ulva sprayer (Herbi) gave $287-293 \mu \mathrm{m}$ droplet size. Labrade et. al. (1994) indicated that most use of the spinning disc or controlled droplet applicator (CDA) has been suitable for insecticide/fungicide application with droplet sizes in the range of 50-150 $\mu \mathrm{m}$. for herbicides droplet sizes larger of 200-300 $\mu \mathrm{m}$ are-common.

\subsection{Deposit Spray on land}

The same trend was observed, where the number of droplet $/ \mathrm{cm}^{2}$ were increased and vice versa droplet sizes were decreased with decreasing spray volume under various flow rates. This results agree with those of Moshtohry and Ammar (2007) , Abou-Amar (1993) and Ammar (1997). There was no effect of glyphosate rate doses on this characters this was true in both seasons .

\subsection{Applicator contamination}

Data in table (2) clearly indicated the occurrence of great reduction in number of droplets/ $\mathrm{cm}^{2}$ deposited on applicator with the spray of glybhosate by flat fan $02-$ F110 nozzle and spinning disc / at $6.4 \%$ and $10 \%$ respectively in the first season and $9.1 \% \& 10.1 \%$, respectively at the second season as compared with fan style spray head which gave $16 \% \& 14.7 \%$ contamination of applicator at first and second seasons, respectively. These results suggest that the drift of spraying was less with the use of these nozzles types on non target organisms. These findings were in agreement with those obtained by Ammar (2003), Moshtohry and Ammar (2007), Bradford et. al. (2003) and Fietsame et. al. (2004). 


\section{Effect of different spraying volumes and rates doses of glyphosate application on the efficacy against the dominated weeds}

\subsection{Annual weeds}

Data in table (3) indicated that, in general, the full rate doses $2.5 \mathrm{~L} . /$ Fed. of glyposate at different spraying volumes had no significant differences on the control of annual weeds. In case of Micron Ulva sprayer (Herbi) at 19 L./Fed. gave good efficacy $(86.9 \%)$ against annual weeds similar to Besho sprayer at $70 \mathrm{l} /$ Fed. achieving reduction of $86.1 \%$ at $2.5 \mathrm{l} / \mathrm{fad}$ glyphosate at the first season. No significant differences were observed at used flat fan 02-F110 and TK1 nozzles were used at 60 and $125 \mathrm{~L}$./Fed. respectively they gave reduction of $91.3 \%$ and $90.9 \%$ respectively on annual weeds at rate dose $2.5 \mathrm{~L}$./Fed. of glyphosate similar to TK1 nozzle at rate dose 4 L./Fed. during 2009. low rate dose of 1.25 L./Fed. gave 80.9, 75.2,81.1 and 82.3\% reduction in case of TK1, spinning disc, flat fan 02- F110 and fan style spray head, respectively. Weeds control was exceeded hand hoeing. The same trend of results was obtained at second season with all treatment.

\subsection{Perennial weeds}

Data in table (3) indicated that, Cp-3 sprayer with fitted flat fan 02- F110 and TK1 nozzles gave good controlling of weeds, reaching (91.42 \& 89.6\%) and (94.2 \& 91.2 ) of perennial weeds sprayed with glyphosate at 2.5 L./Fed. without significant difference with high rate ( 4 L./Fed.) at both seasons, respectively. Also in case of Micron Ulva sprayer at 19 L./Fed. and Besho sprayer at 70 L./Fed. achieved gave control percent ranged from $81.5 \%$ to $87.0 \%$ with glyphsate at 2.5 L./Fed. during both seasons. Also, there were no significant difference between spraying volumes in both seasons at with low rate dose of glyphosate $1.25 \mathrm{~L}$./Fed. 
Table 3. Effect of spraying volumes and rates doses of glyphosate on control \% of annual, perennial and total weeds at 2009 and 2010 season's.

\begin{tabular}{|c|c|c|c|c|c|c|c|c|c|c|c|c|c|c|c|}
\hline \multirow{3}{*}{$\begin{array}{c}\text { Rate doses } \\
\text { of } \\
\text { Glyphosate }\end{array}$} & \multirow{3}{*}{\multicolumn{2}{|c|}{$\begin{array}{l}\text { Nozzle } \\
\text { Type }\end{array}$}} & \multirow{3}{*}{$\begin{array}{c}\text { Spray } \\
\text { volume } \\
\text { L./fad }\end{array}$} & \multicolumn{6}{|c|}{2009 season } & \multicolumn{6}{|c|}{2010 season } \\
\hline & & & & \multicolumn{2}{|c|}{ Annual weed } & \multicolumn{2}{|c|}{ Perennial weed } & \multicolumn{2}{|c|}{ Total weed } & \multicolumn{2}{|c|}{ Annual weed } & \multicolumn{2}{|c|}{ Perennial weed } & \multicolumn{2}{|c|}{ Total weed } \\
\hline & & & & $\mathrm{g} / \mathrm{m}^{2}$ & Control\% & $\mathrm{g} / \mathrm{m}^{2}$ & Control\% & $\mathrm{g} / \mathrm{m}^{2}$ & Control\% & $\mathrm{g} / \mathrm{m}^{2}$ & Control\% & $\mathrm{g} / \mathrm{m}^{2}$ & Control\% & $\mathrm{g} / \mathrm{m}^{2}$ & Control\% \\
\hline 4 & \multirow{5}{*}{$\begin{array}{l}\bar{Q} \\
\overline{0} \\
\overline{0} \\
\overline{0} \\
m \\
\overline{1}\end{array}$} & Tk1 & 125 & 43.5 & 94.5 & 53.8 & 93.8 & 97.3 & 94.1 & 15 & 96.8 & 17 & 96.6 & 32 & 96.7 \\
\hline 2.5 & & Tk1 & 125 & 71.3 & 90.9 & 90.0 & 89.6 & 161.3 & 90.2 & 42.5 & 91.1 & 43.8 & 91.2 & 87.5 & 90.9 \\
\hline 1.25 & & Tk1 & 125 & 150 & 80.9 & 218.8 & 74.7 & 368.8 & 77.7 & 97.0 & 79.8 & 118.8 & 76.3 & 215.8 & 77.5 \\
\hline 2.5 & & $\begin{array}{c}02- \\
\text { f110 }\end{array}$ & 60 & 68.8 & 91.3 & 75.0 & 91.4 & 143.8 & 91.3 & 30.0 & 93.7 & 27.5 & 94.5 & 57.5 & 94.0 \\
\hline 1.25 & & $\begin{array}{r}02- \\
f 110 \\
\end{array}$ & 60 & 148.8 & 81.1 & 197.5 & 77.2 & 346.3 & 79.0 & 95.8 & 80.1 & 112.5 & 77.6 & 208.3 & 78.3 \\
\hline 2.5 & \multirow{2}{*}{\multicolumn{2}{|c|}{$\begin{array}{l}\text { Micron Ulva } \\
\text { sprayer (Herbi) }\end{array}$}} & 19 & 102.5 & 86.9 & 132.5 & 84.7 & 235.0 & 85.8 & 60.8 & 87.4 & 65.0 & 87.0 & 125.8 & 86.9 \\
\hline 1.25 & & & 19 & 195.0 & 75.2 & 260.0 & 70.0 & 455 & 72.5 & 118.3 & 75.9 & 126.3 & 74.8 & 242.5 & 74.7 \\
\hline 2.5 & \multirow{2}{*}{\multicolumn{2}{|c|}{$\begin{array}{l}\text { Besho + Fan } \\
\text { style spray heed }\end{array}$}} & 70 & 109.5 & 86.1 & 128.8 & 85.2 & 238.3 & 85.6 & 83.8 & 82.6 & 92.5 & 81.5 & 176.3 & 81.6 \\
\hline 1.25 & & & 70 & 139.5 & 82.3 & 243.8 & 71.9 & 383.3 & 76.8 & 101.3 & 79.0 & 145.0 & 71.1 & 246.3 & 74.3 \\
\hline \multicolumn{3}{|c|}{ Hand hoeing } & & 232.5 & 70.4 & 313.8 & 63.8 & 546.3 & 66.9 & 121.3 & 74.8 & 142.5 & 71.6 & 263.8 & 72.5 \\
\hline \multicolumn{3}{|c|}{ Unweed check } & & 786.3 & & 867.5 & & 1652.5 & & 482.5 & & 502.5 & & 960 & \\
\hline & S.D & & & 186.1 & & 234.7 & & 420.3 & & 113.3 & & 126.8 & & 237.8 & \\
\hline
\end{tabular}


High rate dose recorded the best herbicidal effects in perennial weed control, and significant exceed than low rates doses with different spraying volumes from equipment used.

\subsection{Total weeds}

Results in table (3) indicated that in both seasons the high rate dose of glyphosate gave excellent control of total weeds when applying with all sprayers ranged from $81.6 \%$ to $94.0 \%$ reduction. The low rate (1.25 l/ Fed.) gave control ranged from $72.5 \%$ to $79.0 \%$ reduction with the same sprayers.

The present results are in harmony with those obtained by Gebhdrdt et. al. (1985), Bradford et. al. (2003), they mentioned that glyphosate efficacy was increased when applied at lower carrier spray volumes with specific nozzle as compared to standard carrier spray volumes. On the other hand, the low rate dose of Herbazed $48 \%$ WSC at $1.25 \mathrm{~L}$./Fed. could be used as alternative to hand hoeing in controlling annual weeds. The high sensitivity of annual species to low rate dose of glyphosate is attributed to less lignified tissues in annual weeds than in perennial weeds.

\section{CONCLUSION}

In general, all the tested spraying techniques gave satisfactory coverage on weeds, it could be concluded that applying glyphosate at the $2.5 \mathrm{~L}$./Fed. with low volume spraying reduced droplet sizes $(\mu \mathrm{m})$ and increased number of droplet $/ \mathrm{cm}^{2}$ which gave reasonable homogeneous distribution of droplets on weed leaves, reduced lost spray on land, reduced applicator contamination and gave enough control of broad leaves and grassy weeds similar to that obtained with TK1 nozzle when applied at the high rate dose at $4.0 \mathrm{l} /$ Fed.. The low rate of glyphosate applied at rate dose 1.25 L./Fed. was effective and sufficient in controlling annual weeds with the use of obvious spraying volumes.

\section{REFERENCES}

1. Abou- Amer, A. M. 1993. Spray spectrum of insecticide deposit the cotton canopy after using different spraying techniques. Ph. D. thesis, Fac. of Agric., Cairo university, Egypt, pp 179.

2. Ammar, A. E. 1997. Studies on certain aerial and ground techniques for controlling the common sucking insect of cotton M. Sc. Thesis, Fac., Agric., Zagazig Univ., pp 86. 
3. Ammar, A. E. 2003. Studies on certain techniques for pesticide applications. Ph.D. Thesis. Fac. Zagazig. Univ., pp 169.

4. Barzee, M.A. and E.W. Stroube. 1972. Low-volume application of pre emergence herbicides. Weed Sci. $20: 176-180$.

5. Bradford,. K.R., C. Messersmith and J.D. Nalewja. 2003. Spray volumes formulation sulfate and nozzle effect on glyphosate efficacy. Weed Technical. 17 : 589-958.

6. Ciba Geigy. 1990. spray volume recommendation for field crops (1989). International training course for the safe and efficient handling and application of plant protection agents. Ciba Geigy Agric. Div. Applic. Advisory Serv . Vol. I, : 1-6.

7. Feng, P.C., J.S. Rywese and R.D. Sammons. 1998. Correlation of lead damage with uptake and translocation of glyphosate in velvetleaf (Abutilon theophrasti) weed technol-12:300-307.

8. Fietsam, J.F. B.G. young and R.W. Steffen. 2004. Differential response of herbicide drift reduction to drift control agents with glyphosate, transactions of the ASAE. 47 (5) : 1405 - 1411.

9. Gabir, I., Zidan, A. Z.H, E.Hallah and M.A. Hindy. 1982. Calibration and evaluation of the: performance of certain hydraulic nozzle types under laboratory conditions. Res. Bull 1783 fac. Agric. Ainshams univ. :19.

10. Gebhardt, M. R., C. L. Webber and L. F. Bouse. 1985. Comparison of a rotary atomizer to a fan nozzle for herbicide application. Trans actions of the ASAE. : 382-397.

11. Labrada, R., J. C. Caseley and C. Parker. 1994. weed management for development for developing countries pp 183-22.

12. Moshtohry, M. R. and A.E. Ammar. 2007. Effect of nozzle types, sprayer volumes and rate of glyphosate on droplet numbers, droplet size and its efficiency on weed control in citrus orchards. J. Agric. Sci. Mansoura Univ., 32 (7): 5623- 5634.

13. Snedecor, W. and W. G. Cochran. 1980. statistical Methods. $7^{\text {th }}$ ed. Lowa state Univ. lowa. USA.

14. Swarbrick, J. L. and B. L. Mercado. 1987. Weed science and weed control in southeast Asia.

15. Tackholm, V. 1974. Students flora of Egypt $2^{\text {nd }}$ ed Cairo Univ., Egypt Graphical Service Beirut Lebanon : 888. 


\title{
التقييم الكيفى والحيوى لمبيد الحشائش الجليفوسات باستخلام وسائل رش معينة ومعدلات تطبيق مختلفه فى حدائق المانجو
}

\author{
عبد المجيد السيد عمار \\ قسم بحوث تكنولوجيا الرش - معهز بحوث وقابة النباتات - مركز البحوث الزراعية - الجيزة - مصر
}

أجريت تجربتين حقليتين في محافظة الإسماعيلية لتقييم كفاءة حجوم الرش المختلفة وكذا استخدام معدلات مختلفة من مبيد الجليفوسات لمكافحة الحشائش الحولية والمعمرة في حدائق أثنجار المانجو عمر 7 سنوات خلال الموسم الصيفي لعامي 2010/2009. وكانت التقنيات المختبرة هي الرشاشة CP-3 والمزودة بالبثيوري TK1 والذى يعطى حجم رش قدره 125 لتر/فدان وكذا البشبورى Flat Fan 02-FII0 بحجم رش قدره 19تنز/فدان والرشاشه بيشو والمزودة برأس الرش Fan style spray head والتي تعطي حجم رش قدره 70لنز/فدان وذلك مع استخدام المعدلات المختلفة من جرعات مبيد الجليفوسات

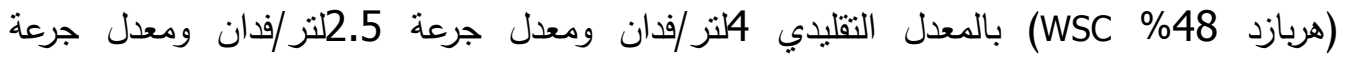
1.25لتر/فدان مع نفس الثقنيات السابقة مقارنة بمعاملة العزيق اليدوى وبدون معاملة. احتوت كل تجربة على إحدى عشر معاملة في تصميم قطاعات كاملة العشوائية في أربعة مكررات. أوضحت الند

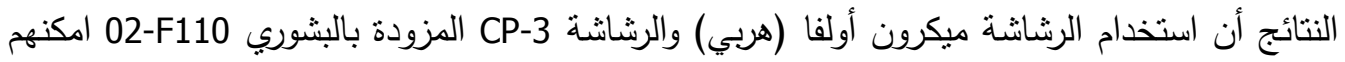
تقليل معدل جرعة المبيد إلى 2.5لتز/فدان عن المعدل التقليدى للجرعة 4لتر/فدان المعامل بالبشوري

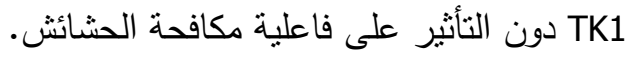

نفس هذه الثقنيات أمكنها خفض التلوث على عامل الرش والذى وصل إلى 6.4\% و 10\%

في الموسم الأول و 9.1\%، 10.1\% في الموسم الثاني على الترتيب. كذا نفس معدل الجرعة 2.5 لنز/فدان من المبيد أعطى نسبة خفض بنفس حجوم الرش كانت 91.3\% ، 85.8\% في الموسم الأول

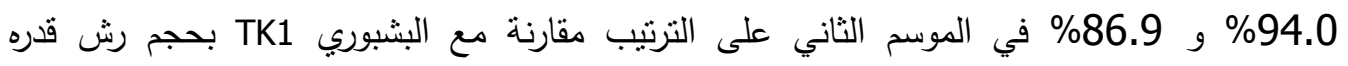
125 لتر/فدان والذي أعطى نسبة مكافحة 94.1\%، 96.7\% في الموسم الأول والثاني على التوالي

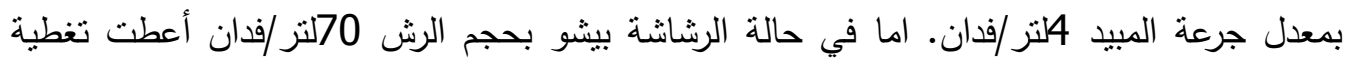
مرضية لراسب الرش على الحشائش تبعه مكافحة جيدة لهذه الحشائش كما أعطى معدل الجرعة

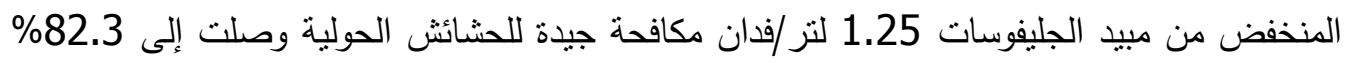
وهي كافية لمكافحة الحشائش الحولية مع استخدام حجوم الرش هذه والتي تفوقت على معاملة العزيق ليقان مع هذه الحشائش.

نخلص من هذه النتائج بأنه باستخدام حجوم الرش المنخفضة يمكن خفض جرعة المبيد الجليفوسات دون وجود فروق معنوية في مكافحة الحشائش الكلية عن المعدل التقليدى لجرعة المبيد

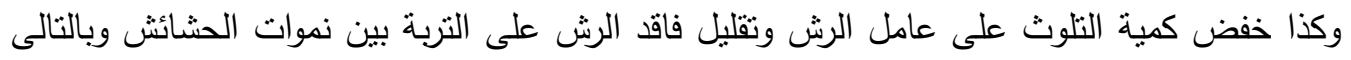
تقليل المخاطر المحتملة على البيئة. 